\title{
A Study of Benthic Macroinvertebrate Community in the Lower Part of Greater Zab River Near Guwer Subdistrict
}

\author{
Yahya A. Shekha \\ Department of Environmental Science \\ College of Science \\ Salahaddin University \\ Erbil, Iraq. \\ Yahya_bio@yahoo.com
}

(Received 21/7/2010; Accepted 6/12/2010)

\begin{abstract}
In this study, the analysis of 48 qualitative macroinvertebrate samples were taken from four sites in the lower reach of Greater Zab river near Guwer subdistrict- Erbil from May 2008- April 2009. Sixteen taxa belong to Ephemeroptera, Diptera, Plecoptera, Hemiptera, in addition to one taxa belong to class Arachnides were identified. Site 1 is characterized by more identified taxa (12 taxa) than the other sites. Most abundant taxa were Tanypus spp. during studied period which followed by Hydrachna spp., with highest $\mathrm{F}$ index percentage reached to $75 \%$ and $58.3 \%$ respectively. According to Sorenson index, sites 2 and 3 were the most similar sites with values reached to $75 \%$.
\end{abstract}

Keywords: Benthic macroinvertebrates, Greater Zab River.

\section{درلسة مجتمع اللفقربك الفاعيةفي الجزء اللفلي لنهر الزلب الأعل قربمظطة الكوبر}

\section{الملغص}

في الدرلسة الحالية , قم تحللي 48 أنمونجاَ من اللافقريك العيانية الملخوذة من الجزء الـ سفلي لنه _ر

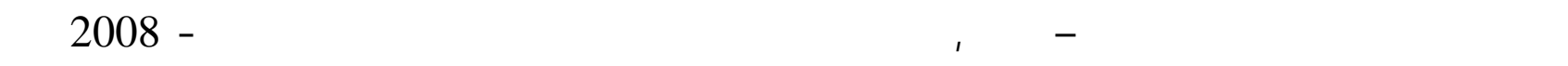
نيسان -2009 .

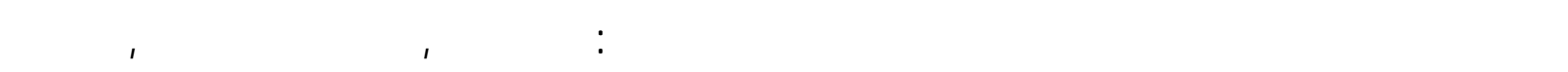

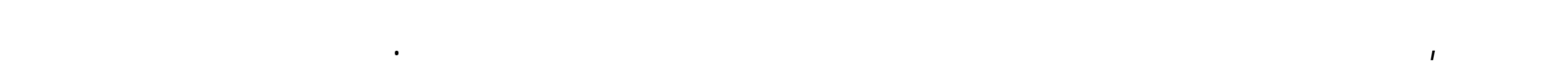

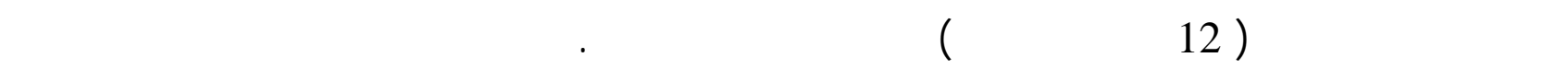

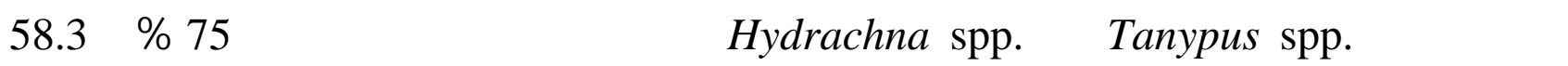

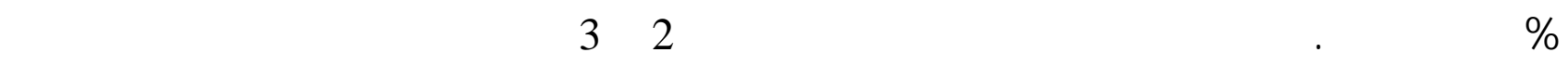
وصلت اللى 75\% . الهاملت الدالة: اللافريكت العيانية القاعية، نهر الزاب الأعله. 


\section{INTRODUCTION}

During the last decades, benthic macroinvertebrates had been the most commonly used group for the assessment of anthropogenic impacts on the quality of surface water (Skoulikidis et al., 2009). Many stream and river assessment methods based on macroinvertebrates which have been developed worldwide and they are the preferred means of assessing aquatic quality (Arimoro and Ikomi, 2009).

Spatial variation in lotic macroinvertebrate community structure due to a combination of intrinsic biotic community interactions, environmental conditions and historical factors (Murphy and Davy-Bowker, 2005). Aquatic insects which are important elements in the ecological dynamics of lotic environment are playing an important role in the cycle of materials and introphic transfers (Hynes, 1970). The communities of aquatic insects are affected by several factors related to water quality, stream morphology and food availability and quality (Bispo et al., 2006 ; Ifigenia et al., 2006).

Many researches had been done during the last three decades concerning aquatic insects in Iraq. Most studies concentrated on Tigris River and their tributaries in northern and a central part of Iraq: (Hussain et al., 1984; Salih et al., 1986 ; Salih et al., 1990).They are made survey of microfauna, macrofauna and zoobenthos in Tigris River at Mosul city. Whereas, (Mohammad, 1980; Al- Mukhtar et al., 1986 ; Saadalla, 1998) studied the impacts of anthropogenic stress on abundance and distribution of benthic invertebrate in Diyala River. Preliminary water quality reports on the Greater Zab River were made by (AlNimma, 1982; Aziz, 1997; Aziz, 2006 ; Lak, 2007) dealt with ecological aspects. While, (Ali, 2006) described microinvertebrate, macroinvertebrate abundance, diversity, ecological variables on communities structure.

The goal of the present paper is to investigate and describe the macroinvertebrate community structure in unperturbed lower reach of Greater Zab River.

\section{MATERIALS AND METHODS}

Greater Zab River is one of the main Tigris River tributaries. It passes through mountains and valley areas and many branches discharged to it. The total length within Iraqi land reached to $171 \mathrm{Km}$. The substrate of the studied portion of the river consist of large stones and pubbles.

Monthly, macroinvertebrate samples were collected at 4 sites from lower stretch of Greater Zab River, from May 2008 to April 2009 (Figure 1). Benthic organisms were collected using a handnet (mesh $<0.3 \mathrm{~mm}$ ), fixed $5 \%$ formalin in the field and preserved with $70 \%$ ethanol in the laboratory. Taxonomic identification of most samples was made to the generic level and some members to the species level through the taxonomic key of (Edmonson, 1959; Quigley, 1977; Macan, 1979; Tachet et al., 1984; Hynes, 1977; Bouchard, 2004).

The frequency of benthic occurrence species were calculated by using the $\mathrm{F}$ index which described by (Muniz and Venturini, 2001): $\mathrm{F}=\mathrm{Pa} / \mathrm{P} * 100$, where: $\mathrm{Pa}=$ is the number of sites where the species are occurred and $\mathrm{P}$ is the total number of sites. Using this formula the species were classified in: Constant species ( $\mathrm{F}>50 \%)$, Common $(10<\mathrm{F}<49 \%)$ and Rarely species ( $\mathrm{F}<10 \%)$.

Sorenson similarity (Hamayoan et al., 2003) was used to compare the sampling locations and to determine which one was similar in taxa composition. $\mathrm{S}=2 \mathrm{~J} /(\mathrm{a}+\mathrm{b}) * 100$, where: $\mathrm{J}=$ 
number of species occurred in both sites. $a=$ number of species occurred in (a) site, b= number of species occurred in (b) site.

\section{RESULT AND DISCUSSION}

Altogether, 17 taxa are belonging to 12 families were identified from quantitative samples. Among them 9 taxa belong to Ephemeroptera were represented by 4 families, 4 taxa to Diptera represented by 4 families, 2 taxa to Plecoptera and one taxa for Hemiptera and class Arachnides.

Baetidae and Ecdyonuridae were the most common families which accounted for $17.6 \%$ of the total taxa collected for each one. Although the number of species were identified in all sites: Isonychia spp., Tanypus spp. and Hydrachna spp. (Table 1).

Site 1 is characterized by more identified taxa (12 species) compared with other sites which are contributed by only 7 species for each one. It may be due to less anthropogenic impacts in site 1 rather than other site downstream it (Shekha, 2008).

Some of description and measurement of taxa are summarized as follows:

Baetis rhodani (Pictet, 1844): Body tapered. top of femora with long and short pointed spines. Small pointed spines on tibiae, base on antennae and edge of gills. Length 12-15 mm.( Plate 1, A, B, C, D).

Rithrogenia semicolorata (Muller, 1776): First pair of gills are very large and meeting beneath the body. Length 15- 18 mm. (Plate 1, E, F, G).

Heptagenia sulphurea (Curtis, 1834): Gills are small and rounded at the tip of lamella. Front edge of femora with fring of fine hairs and spines. (Plate 1, $\mathrm{H}$ ).

Isonychia spp. (Eaton): Fore legs with double rows of long setae, gills oval present on abdominal segments 1- 7: long hairs along the inner margins of caudal filaments. Their size from 8- 17 mm. (Plate 2, A, B, C, D).

Prosopistoma spp.: Body flattened dorsoventrally. A shell covers the chest and part of the abdomen, leaves only the last abdominal segments, gills invisible cachese completely under the shells. Eyes dorsal compounds significantly. (Plate 2, E, G).

Amphinemura spp.: Dark brown color. Long bristle present about two- thirds along length of each femur region of legs. Length up to $6 \mathrm{~mm}$. Gills 4, cervical, with 5 or more branches each). (Plate 3, A, B, C).

Tanypus spp.: Antennae retractile, usually elongated, prolegs long, stilt- like, anterior pair with a common base. Ventral pair of anal gills attached to base of prolegs, remote from anus. Three pairs of anal gills. (Plate 3, D).

Tendipes tentans : Thoracic respiratory organ a tuft of numerous filaments. (Plate 3, E).

Simulium spp.: Head with a pair of prominent mouth brushes. Hooked false leg on thorax. Abdomen ends in an attachment organ of radial rows of strong hooks. Length 10 mm. (Plate 3, F, G).

The larva of Chironomidae (Tanypus spp.) were the most dominant species which presenting in all sites during studied period with frequent percentage (F \%) 66.6, 41.6, 75, $66.6 \%$ respectively (Tables $2,3,4,5$ ). These are represented as constant species (Muniz and Venturini, 2001). (Al- Mukhtar et al., 1986 ; Saadalla, 1998) have found that Chironomide larva represents higher than $50 \%$ of benthic fauna in Diyala river. Chironomidae are broadly distributed worldwide and frequently which are the most abundant insects in many freshwater ecosystems (Callisto et al., 2002 ; Garcia and Suarez, 2007). Furthermore, their quick generation turnover and rapid growth guarantee are an availability of biomass to 
aquatic ecosystem dynamics (Marques et al., 1999). On the other hand, Hydrachna sp. was the second abundant species in all sites with $\mathrm{F}$ index 16.6, 33.3, 58.3, 33.3\% respectively. Ali (2006) recorded Hydrachna spp. in Khabat site in Greater Zab River during July and August. Isonychia spp. was identified in all sites. It is regarded as common species in sites 2 and 3 and as rare species in sites 1 and 4. Ali (2006) found same species in Greater Zab River.

The following species were restricted to site 1 alone: Baetis tenax , B. vernus, Brachycercus harrisella, Ecdyonurus spp., Prosopistoma spp. and Amphinemoura spp. According to the Sorensen coefficient of similarity site 2 was similar to site $3(75 \%)$ and site 4 (62.5\%) (Table 6). Each site accounted by 7 identified taxa. 


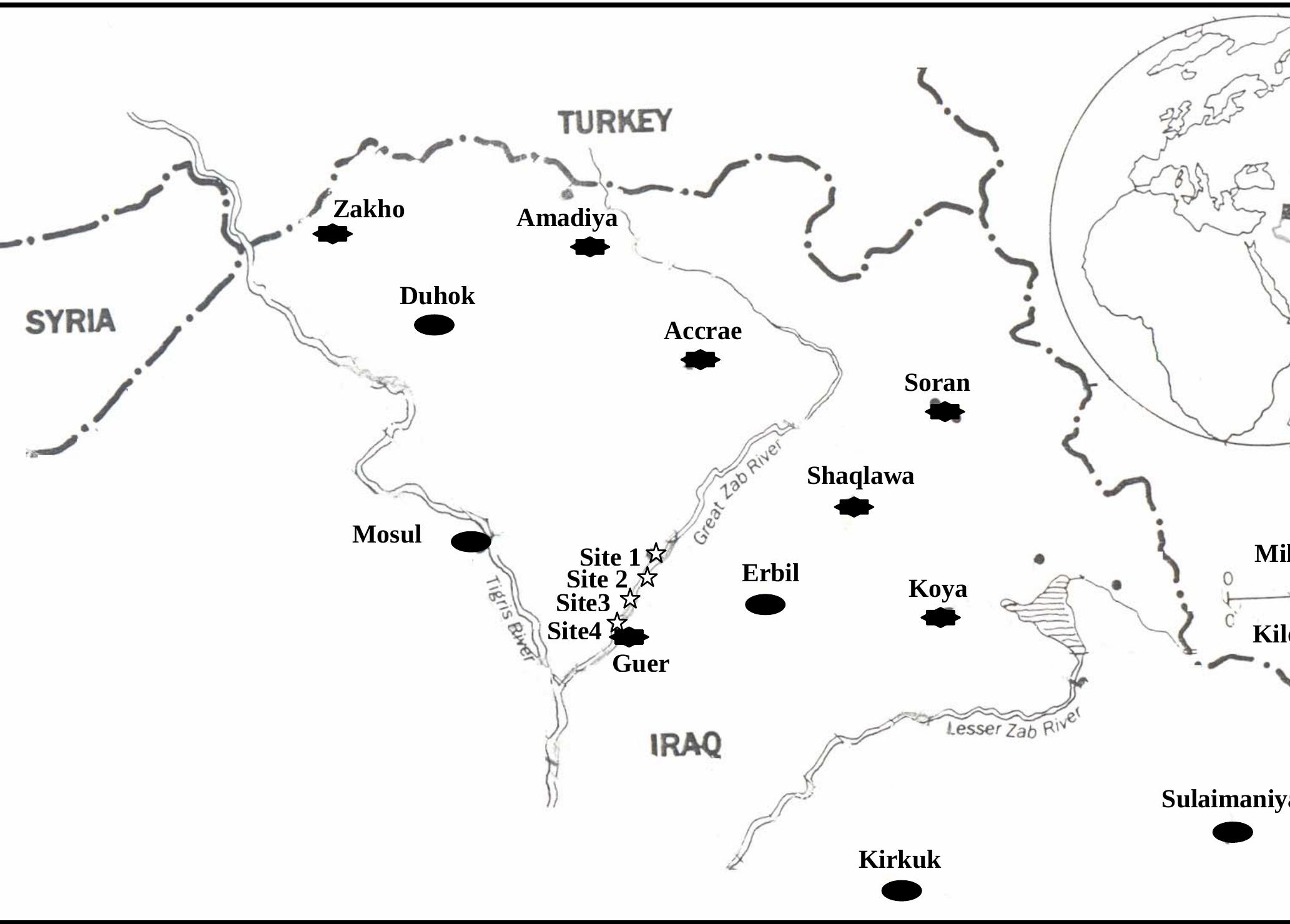

Map 1: Shows:

A- Map of the area.

B- Studied sites. 
Table 1: List of macroinvertebrates recorded during studied period.

\begin{tabular}{|c|c|c|c|c|}
\hline \multirow[t]{2}{*}{ Macro invertebrates } & \multicolumn{4}{|c|}{ Sites } \\
\hline & 1 & 2 & 3 & 4 \\
\hline \multicolumn{5}{|l|}{$\begin{array}{c}\text { Class Insecta } \\
\text { Order Ephemeroptera } \\
\text { Family Baetidae }\end{array}$} \\
\hline Baetis rhodani (Pictet, 1844) & + & & + & + \\
\hline Baetis vernus (Curtis, 1834) & + & & & \\
\hline Baetis tenax ( Eaton, 1870) & + & & & \\
\hline \multicolumn{5}{|l|}{ Family Caenidae } \\
\hline Brachycercus harrisella (Curtis, 1834) & + & & & \\
\hline Caenis horaria (Linnaeus, 1758) & + & & + & \\
\hline \multicolumn{5}{|l|}{ Family Ecdyonuridae } \\
\hline Heptagenia sulphurea (Muller, 1776) & & & & + \\
\hline Rhithogenia semicolorata (Curtis, 1834) & & & & + \\
\hline Ecdyonurus spp. ( Eaton, 1868) & + & & & \\
\hline \multicolumn{5}{|l|}{$\begin{array}{l}\text { Family Siphlonuridae } \\
\text { Subfamily Isonychia }\end{array}$} \\
\hline Isonychia spp. (Eaton) & & + & + & \\
\hline \multicolumn{5}{|l|}{ Family: Prosopistomatidae } \\
\hline Prosopistoma spp. & + & & & \\
\hline \multicolumn{5}{|l|}{$\begin{array}{c}\text { Order Diptera } \\
\text { Family Chironomidae } \\
\text { Subfamily Tanypodinae }\end{array}$} \\
\hline Tanypus spp. (Meigen) & + & + & + & + \\
\hline \multicolumn{5}{|l|}{$\begin{array}{l}\text { Family Tendipedidae } \\
\text { Subfamily Tendipedinae }\end{array}$} \\
\hline Tendipes tentans & & + & + & + \\
\hline \multicolumn{5}{|l|}{$\begin{array}{c}\text { Family Culicidae } \\
\text { Subfamily Culicinae }\end{array}$} \\
\hline Culex spp. (Linnaeus, 1758) & & + & & \\
\hline \multicolumn{5}{|l|}{ Family Simuliidae } \\
\hline Simulium spp. & + & + & + & \\
\hline \multicolumn{5}{|l|}{$\begin{array}{c}\text { Order Plecoptera } \\
\text { Family Nemouridae }\end{array}$} \\
\hline Amphinemoura spp. & + & & & \\
\hline \multicolumn{5}{|l|}{$\begin{array}{l}\text { Order Hemiptera } \\
\text { Family Corixidae }\end{array}$} \\
\hline Sigara spp. & + & + & & + \\
\hline \multicolumn{5}{|l|}{$\begin{array}{c}\text { Class Arachnides } \\
\text { Order Acari } \\
\text { Family Hydrachnidae }\end{array}$} \\
\hline Hydrachna spp. (Muller, 1776) & + & + & + & + \\
\hline Total number of taxa & 2 & 7 & 7 & 7 \\
\hline
\end{tabular}

$+=$ taxa detected 
Table 2: Monthly recorded of macroinvertebrates in site 1, with their constant index percentage.

\begin{tabular}{|c|c|c|c|c|c|c|c|c|c|c|c|c|c|}
\hline \multirow{2}{*}{ Taxa } & \multicolumn{9}{|c|}{ 2008 } & \multicolumn{3}{c|}{ 2009 } & F \\
& May & June & July & Aug. & Sept. & Oct. & Nov. & Dec. & Jan. & Feb. & Mar. & Apr. & $\begin{array}{c}\text { inde } \\
\text { x \% }\end{array}$ \\
\hline Baetis rhodani & & & + & & & & + & & & & & & 16.6 \\
\hline Baetis vernus & & & + & & & & & & & & & & 8.3 \\
\hline Baetis tenax & & & + & & & & & & & & & & 8.3 \\
\hline Isonychia spp. & & & + & & & & & & & & & & 8.3 \\
\hline $\begin{array}{c}\text { Brachycercus } \\
\text { harrisella }\end{array}$ & & & + & & & & & & & & & & 8.3 \\
\hline Caenis horaria & & & + & & & & & & & & & & 8.3 \\
\hline Ecdyonurus spp. & & & + & & & & & & & & & & 8.3 \\
\hline Prosopistoma spp. & & & + & & & & & & & & & & 8.3 \\
\hline Tanypus spp. & & + & + & + & & + & + & & + & + & + & & 66.6 \\
\hline Simulium spp. & & & & & & & & & & & & + & 8.3 \\
\hline Amphinemura spp. & & & + & & & & & & & & & & 8.3 \\
\hline Sigara spp. & & & & & & & + & & & & & & 8.3 \\
\hline Hydrachna spp. & & & & & & & + & & & + & & & 16.6 \\
\hline
\end{tabular}

$+=$ detected

Table 3: Monthly recorded of macroinvertebrates in site 2, with their constant index percentage.

\begin{tabular}{|c|c|c|c|c|c|c|c|c|c|c|c|c|}
\hline \multirow[t]{2}{*}{ Taxa } & \multicolumn{8}{|c|}{2008} & \multicolumn{4}{|c|}{2009} \\
\hline & May & June & July & Aug. & Sept. & Oct. & Nov. & Dec. & Jan. & Feb. & Mar. & Apr. \\
\hline Isonychia spp. & + & + & & & & & + & & & & & \\
\hline Tanypus spp. & & & + & + & + & & & & & + & & + \\
\hline Tendipes tentans & & + & & & & & & & & + & & \\
\hline Culex spp. & & & + & & & + & & & & & & \\
\hline Simulium spp. & & & + & & & & & & & & & \\
\hline Sigara spp. & & & & & & & + & & & & & \\
\hline Hydrachna spp. & & + & & & & + & + & + & & & & \\
\hline
\end{tabular}


Table 4: Monthly recorded of macroinvertebrates in site 3, with their constant index percentage.

\begin{tabular}{|c|c|c|c|c|c|c|c|c|c|}
\hline \multirow[t]{2}{*}{ Taxa } & \multicolumn{8}{|c|}{2008} & \multirow[b]{2}{*}{ Jan. } \\
\hline & May & June & July & Aug. & Sept. & Oct. & Nov. & Dec. & \\
\hline Baetis rhodani & & & + & & & & + & & \\
\hline Caenis horaria & & & & & & & & & \\
\hline Isonychia spp. & + & + & & & & & & & + \\
\hline Tanypus spp. & + & + & + & + & & + & + & + & \\
\hline Tendipes tentans & & & & & + & & & & \\
\hline Simulium spp. & & + & & & & & & & \\
\hline Hydrachna spp. & & + & & + & + & + & & & + \\
\hline
\end{tabular}

+ = detected

Table 5: Monthly recorded of macroinvertebrates in site 4, with their constant index percentage.

\begin{tabular}{|c|c|c|c|c|c|c|c|c|c|c|}
\hline \multirow[t]{2}{*}{ Taxa } & \multicolumn{8}{|c|}{2008} & \multirow[b]{2}{*}{ Jan. } & \\
\hline & May & June & July & Aug. & Sept. & Oct. & Nov. & Dec. & & $\mathbf{F}$ \\
\hline Baetis rhodani & & & + & & & & & & & \\
\hline Isonychia spp. & & & + & & & & & & & \\
\hline Heptagenia sulphurea & & + & & & & & & & & \\
\hline Rhithogenia semicolorata & & + & & & & & & & & \\
\hline Tanypus spp. & + & + & + & & & & + & & + & \\
\hline Tendipes tentans & & + & & & & & & & & \\
\hline Sigara spp. & & & & & + & + & & & & \\
\hline Hydrachna spp. & & + & + & & & & & + & & \\
\hline
\end{tabular}

Table 6: Sorenson similarity index (\%) between sites during studied period.

\begin{tabular}{|c|c|c|c|}
\hline Sites & $\mathbf{2}$ & $\mathbf{3}$ & $\mathbf{4}$ \\
\hline 1 & 47.62 & 57.10 & 47.62 \\
\hline 2 & & 75.00 & 62.50 \\
\hline 3 & & & 60.50 \\
\hline
\end{tabular}



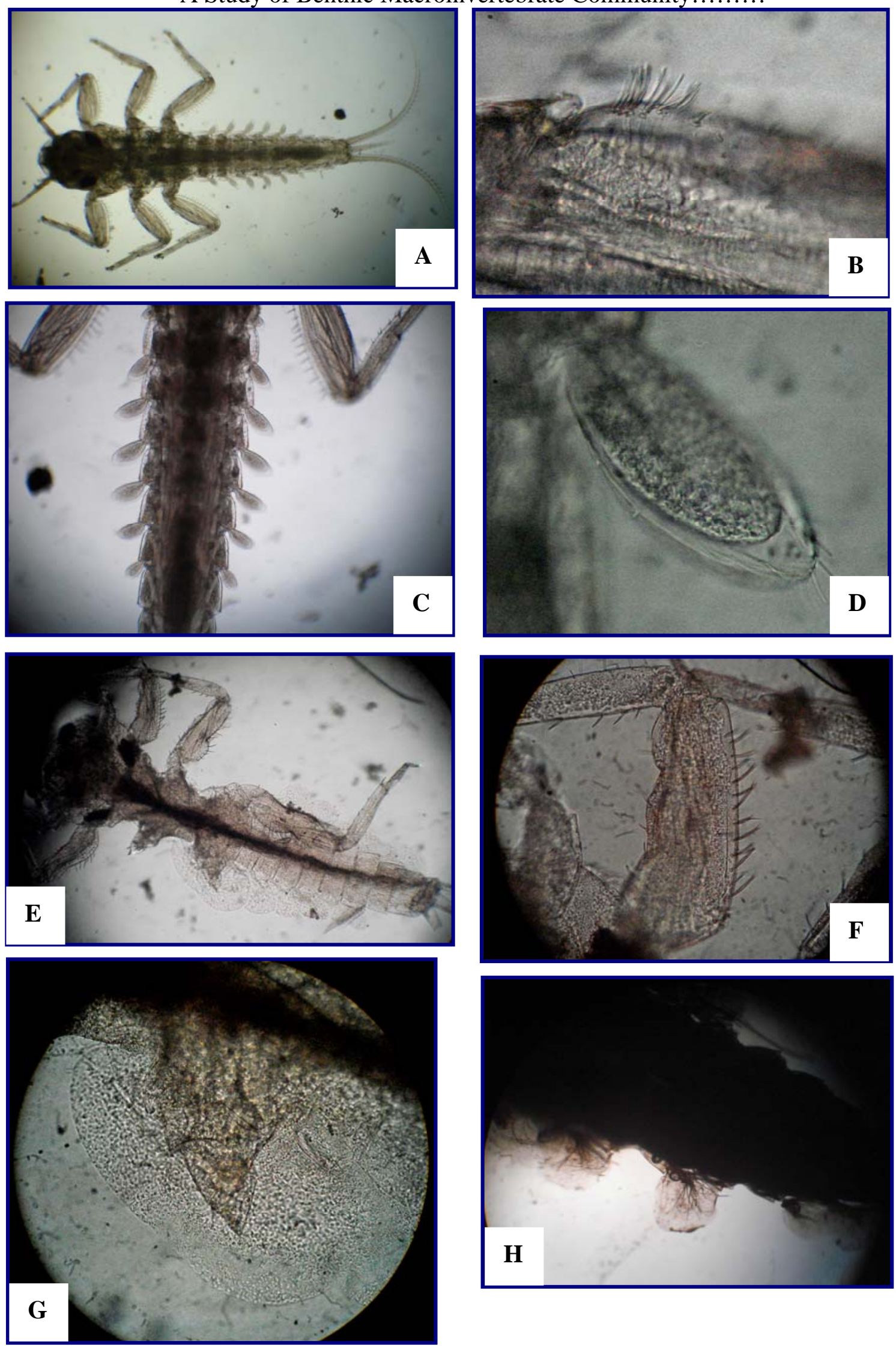

Plate 1: Structure of Ephemeroptera. A. Baetis rhodani whole body (4X). B. B. rhodani spine on fore leg (40X). C. B. rhodani gills on abdominal segments (10X). D. B. rhodani gill with tufs on its final end (40X). E. Rhithrogena semicolata whole body (4X). F. R. semicolata hairs and spines on fore leg (40X). G. R. semi. first gill very large (40X). H. Heptagenia sulphurea gills oval shape (10X). 

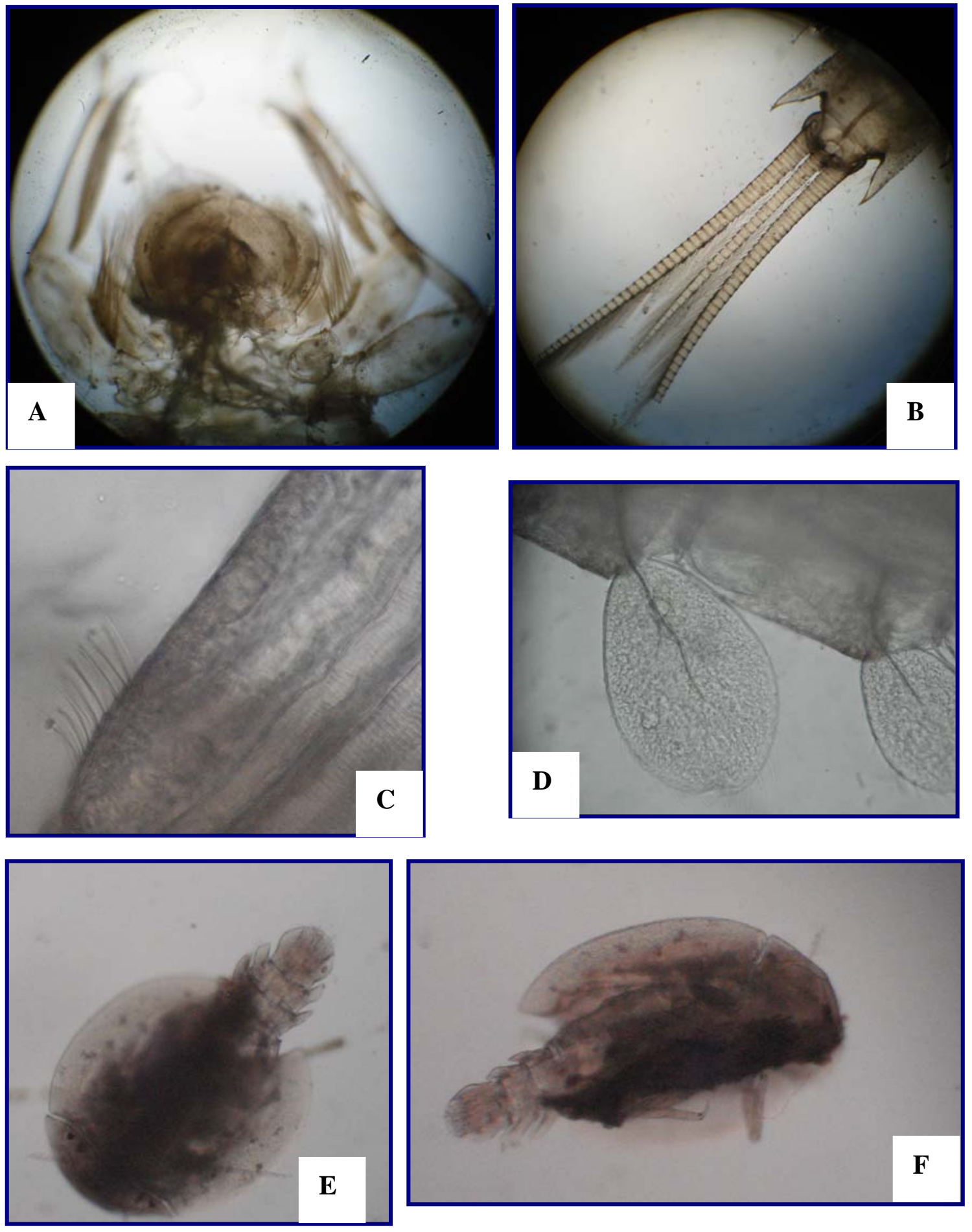

Plate 2: Structure of Ephemeroptera A. Isonychia spp. long setae on fore legs (10X). B. Isonychia spp. Caudal filaments (10X). C. Isonychia spp. bundle of setae on femora (40X). D. Isonychia spp. oval gills (40X). E. Prosopistoma spp. dorsal view of body (4X). F. Prosopistoma spp. lateral view of body (4X) 

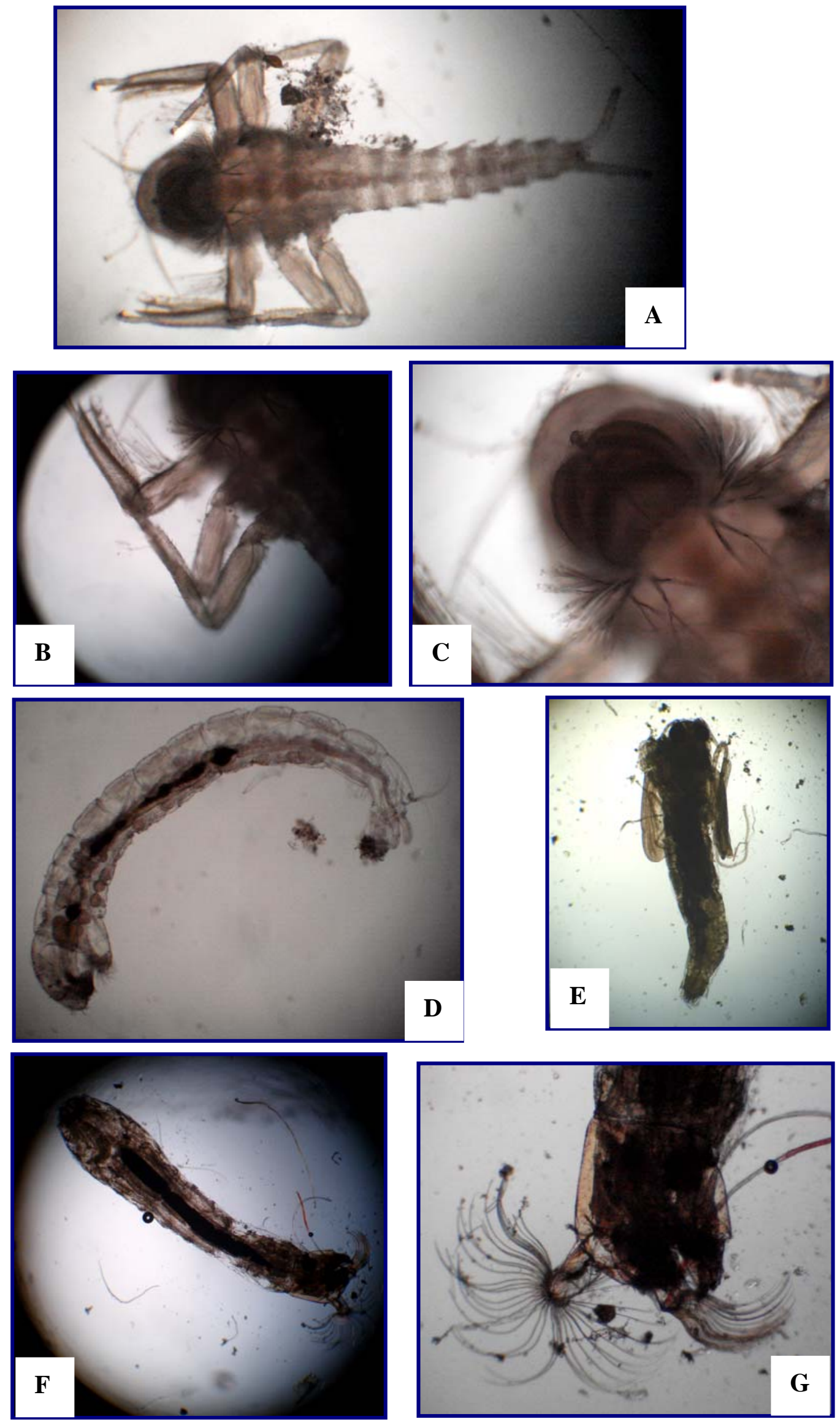

Plate 3: A. Amphinemoura spp. whole body (4X). B. Amphinemoura spp. long setae on fore leg (7X). C. Amphinemoura spp. bunches of filamentous gills on posternum (10X). D. Tanypus spp. whole body (4X). E. Tendipens tentans whole body (4X). F. Simulium spp. whole body (4X). Simulium spp. a pair of folding fans (10X). 


\section{REFERENCES}

Ali, L.A. (2006). A study of macroinvertebrates community in the middle sector of Greater Zab river, Iraq. Ph.D. Thesis. Univ. of Baghdad. Iraq.

Al-Mukhtar, E. A.; Al-Dabbagh, K.Y.; Taha, T.M. (1986). The benthic fauna of the polluted lower part of river Diyala, central Iraq. J. Boil. Sci. Center., 17(3), 35- 45.

Al-Nimma, B.A.B. (1982). A study on the limnology of the Tigris and Euphrates rivers. M.Sc. Thesis. Univ. of Salahaddin - Erbil. Iraq.

Arimoro, F. O. ; Ikomi, R. B. (2009). Ecological integrity of upper warri river, Niger Delta using aquatic insects as bioindicators. Limnologica. 9, 455- 461.

Aziz, F.H. (1997). A phycological study with particular references to Rawanduz river path within Erbil province, Iraq. Ph.D. Thesis. Univ. of Salahaddin - Erbil. Iraq.

Aziz, S.Q. (2006). Assessment of Greater Zab river water quality at Efraz station for drinking and irrigation purposes. Zanco J., 18(3), 131- 144.

Bispo, P.C.; Oliveira, L. G.; Bini, L.M.; Sousa, K. G. (2006). Epheromeptera, Plecoptera and Tricoptera assemblages from riffles in mountain streams of central Brazil: Environmental factors influencing the distribution and abundance of immatures. Braz. J. Biol., 66(2B), 611- 622.

Bouchard, R. W. (2004). "Guide to Aquatic Macroinvertebrates of the Upper Midwest". Water Resources Center", Univ. of Minnesota. USA. 208p.

Callisto, M.; Moreno, P.; Goncalves, J. F.; Leal, J. J. F.; Esteves, F. A. (2002). Diversity and biomass of Chironomidae (Diptera) larvae in an impacted coastal lagoon in Rio De Janeiro, Brazil. Brazil J. Biol., 62(1), 77- 84.

Edmonson, W.T. (1959). "Freshwater Biology". 2nd.edn. John Wiely and Sons, Inc. 1248p.

Garcia, P. E. ; Suarez, D. A. A. (2007). Community structure and philology of Chironomids (Insecta: Chironomidae) in a Patagonian Andean stream. Limnologica., 37, 109117.

Hamayoan, S.B.; Nasreen, B.; James, T.C. (2003). Depth distribution of microbial diversity in Mono lake, a meromectic soda lake in California. Appl. and Environ. Microbial., 69(2),1030- 1042.

Hussain, M.A.; Aziz, J.B.; Al-Hilly, E. (1984). A survey of the microinvertebrates and macroinvertebrates fauna with special reference to Ciliophora (Protozoa) and Chironomidae (Diptera) in certain freshwater bodies of Mosul ( Nineva- Iraq) and environs, 3rd Arabic Sci. Conf. Biol. Sci. Amman- Jordan. 76.

Hynes, H. B. N. (1970). "The Ecology of Running Waters". Liverpool Univer. Press. UK. 555p.

Hynes, H. B. N. (1977). "A key to the Adults and Nymphs of the British Stoneflies (Plecoptera): With Notes on Ecology and Distribution". Freshwater Biological Association Scientific Pub. No.17. 95p.

Ifigenia, K.; Economidis, G.; Leonardos, I.; Papaloukas, C. (2006). Assessment of a mediterranean shallow lentic ecosystem (lake Pamvotis, Greece) using benthic community diversity: response to environmental parameters. Limnologica. 36, 269278.

Lak, M.H.H. (2007). Environmental study of Arab-kand wastewater channel in Erbil governorate, Kurdistan region. Iraq. M.Sc. Thesis. Univ. of Salahaddin -Erbil. Iraq.

Macan, T. T. (1979). "A key to the Nymphs of British Ephemeroptera". 3rd.edn. Freshwater Biological Association Scientific Pub. No.20. 81p. 
Marques, M. M.; Barbosa, F. A. R.; Callisto, M. (1999). Distribution and abundance of Chironomidae (Diptera, Insecta) in an impacted watershed in shouth- east Brazil. Rev. Brasilian Biol., 59(4), 553- 561.

Mohammed, M-B., F.L.S. (1980). A hydrological survey of a polluted canal. Hydrobio., 74,179- 186.

Muniz, P.; Venturini, N. (2001). Spatial distribution of the macrozoobenthos in the Solis Grande stream estuary (Canelones- Maldonado, Uruguay). Brazil J. Biol., 61(3), 409- 420.

Murphy, J.F.; Davy- Bowker, J. (2005). Spatial structure in lotic macroinvertebrate communities in England and Wales: relationship with physical, chemical and anthropogenic stress variables. Hydrobio., 534, 151- 164.

Quigley, M. (1977). "Invertebrates of Streams and Rivers: A key to Identification". Edward Arnold Pub. UK. 84p.

Saadalla, H.A.A. (1998). Ecological study on the effect of Himreen impoundment on the benthic and planktonic invertebrates of river Diyala. Ph.D. Thesis. Univ. of Baghdad, Iraq.

Salih, T. M.; Aziz, G. B.; A- Qaddo, S. M. (1990). The influence of some factors on the distribution of Chironomid larvae in Saddam dam lake and Tigris River. 2nd. Sci. Conf. of S. D. R. C. Univ. of Mosul, Iraq. B-20 March, pp. 130- 142.

Salih, T. M.; Al-Habbib, O.A.M.; Rao, K. S.; Saleem, K. M. ; Hilly, I. A. (1986). Limnological studies on river Tigris: Observations on gross water quality fluctuations and macrozoobenthos. Hydrobio., 2(3),17- 23.

Shekha, Y.A. (2008). The effect of Erbil city wastewater discharge on water quality of Greater Zab river, and the risks of irrigation. Ph.D. Thesis. Baghdad University. Iraq.

Skoulikidis, N. T.; Karaouzas, I. ; Gritzalis, K. C. (2009). Identified key environmental variables structuring benthic fauna for establishing a biotic typology for Greek running waters. Limnologica., 39, 56- 66.

Tachet, H.; Bournaud, M.; Richoux, P. (1984). "Introduction a Letude Des Macroinvertebres Des Eaux Douces". 2nd. edn. Association Francaise de Limnologie. 156p. 